\title{
Implementation of Web-Based Customer Relationship Management at PT. Kimia Farma Trading and Distribution Palembang
}

\author{
ADAWIYAH $^{1}$, Mira AFRINA ${ }^{2}$

\begin{abstract}
${ }^{1}$ adawiyah.wiwid@gmail.com, Information System Department, Faculty of Computer Science, Sriwijaya University, Palembang, Indonesia

${ }^{2}$ miraafrina81@gmail.com, Information System Department, Faculty of Computer Science, Sriwijaya University, Palembang, Indonesia
\end{abstract}

\begin{abstract}
PT. Kimia Farma Trading and Distribution is a company engaged in the trading and distribution of pharmaceutical products. This research uses the Customer Relationship Management (CRM) method as an effort to get new customers, increase relationships and maintain customer loyalty. The system development method used in this research is the Framework for the Application of System Thinking (FAST) method. The final result of this research is Kimia Farma's product sales website with features that support CRM.
\end{abstract}

Keywords: pharmaceutical company, Customer Relationship Management, website

\section{INTRODUCTION}

Nowadays developments in the world of information technology and business are growing rapidly. This condition causes business people to use various strategies to improve the quality of their products or services, one of which is by focusing on customer needs.

PT. Kimia Farma Trading and Distribution Palembang or commonly called KFTD is one of the companies engaged in trading services and distribution of pharmaceutical products. The company does not yet have interactive media to convey product information and promote products to customers. Besides, interactions between customers and companies are still limited. Customer data such as purchase transaction reports also have not been used optimally to support business strategies. All the limitations of this interaction cause companies to experience difficulties in studying customer needs and behavior so that product sales are less than optimal. To overcome these problems, we need a system that can build relationships and good communication between KFTD and customers in creating customer confidence to use KFTD services, so that the level of customer satisfaction and loyalty increases. The method used in this research is the Customer Relationship Management (CRM) method.

The purpose of this research is to design a web-based Sales Information System at PT. Kimia Farma Trading and Distribution Palembang and apply the concept of Customer Relationship Management (CRM) to foster good relations with customers and increase customer loyalty.

\section{LITERATURE REVIEW}

\section{Information System}

The information system is a combination of work procedures, information, people, and information technology that is organized to achieve goals in an organization [1].

An information system is a collection of various components that are managed to carry out input and process data and produce output in the form of information needed by an organization to achieve certain goals.

\section{Sales}

Sales is a straightforward concept that includes efforts to persuade customers to buy a product. The goal of sales management is to achieve business development results as planned by motivating sales team members to show their best abilities [2].

\section{Sales Information System}

The Sales information system is a system that functions to process data related to sales activities both from purchase transactions to sales transactions used to support these sales activities [3]. A sales information system is a system used to process data related to sales to support sales activities. 
parties directly related to the sales process carried out so far.

\section{Customer Relationship Management (CRM)}

CRM is a core business strategy that combines internal processes and functions, external networks, to create and deliver value to customers for profit. CRM is based on quality customer data and is made possible by information technology [4].

In CRM there are three main components [5], namely:

\section{Operational CRM}

Operational CRM plays a role in customer interactions, which includes the integrated process automation of the entire business process, such as marketing automation, and service. One of the operational applications of CRM is in the form of a web application. Through the web, a company can provide services to customers.

\section{Collaborative CRM}

Collaborative CRM deals with all the communication needed, coordination, collaboration between sellers and buyers. The goals of Collaborative CRM are quite broad, including improving services and expanding customer loyalty.

\section{Analytical CRM}

Analytical CRM plays a role in carrying out customer and market analysis, such as market trend analysis and analysis of customer needs and behavior. The application of Analytical CRM usually uses a data warehouse or data mining.

There are three phases of CRM [6] namely:

\section{Acquire}

New customers are obtained by promoting products or providing easy access to information, new innovations and attractive services.

\section{Enhance}

The Company can enhance customer value by listening to customer desires and providing good service.

\section{Retain}

Maintaining customers who benefit by customizing services according to what is needed by specific customers, not the market. The company's focus now is on how to retain customers who are certainly profitable for the company.

\section{RESEARCH METHODOLOGY}

\section{METHOD OF COLLECTING DATA}

To obtain the data needed in this study, the author uses the following data collection methods:

1. Field Study

- Interview

In the interview method, the author conducted a question and answer with the
- Observation

In the method of observation, the author makes observations to find the data needed in the implementation of web-based CRM in KFTD Palembang.

2. Literature Study

The Literature study method is a method of collecting data by reading books, reports, articles and journals related to the object of research and can be used as a basis for theory and comparison materials

\section{DATA DESCRIPTION}

The main data needed in research on implementing web-based CRM in this case include:

1. Company Data

It Contains a company profile that is the company name, history, location, vision and mission, and organizational structure in order to see the profile of the company.

2. Customer Data

Customer data is data that contains a customer's identity, such as the name of the pharmacy /outlet, outlet location, and so on.

3. Product Data Product data contains details about the products available at the company.

4. Sales Data

Sales data is data that is a reference in the sales process in KFTD Palembang.

\section{SYSTEM DEVELOPMENT METHOD}

In this study, the author uses the system development method, namely the Framework for the Application of System Techniques (FAST). FAST integrates all known popular approaches into a collection of agile methods or intelligent methods [9].

There are eight development phases in the FAST method, namely:

- Preliminary Investigation Phase

This phase contains initial investigations to design a system, such as interviews, direct reviews and studying company documents. This stage studies matters relating to the object under study namely regarding the sales process in KFTD Palembang by conducting interviews with related parties.

- Problem Analysis Phase

At this stage, some prospective software and hardware will be considered which will be selected and used in the implementation of the system as a solution to the problems and requirements that have been defined in the previous stages.

- Requirement Analysis Phase

At the Requirement analysis stage, analysis of needs is conducted. The aim is to identify the data, processes, and interfaces that the user wants from the new system.

- Logical Design Phase 
The purpose of this stage is to transform business needs from the requirements analysis phase to the system to be built.

\section{- Decision Analysis Phase}

At this stage, an analysis of the decisions to be made is based on the solutions offered. This stage will produce solutions offered for the implementation of web-based CRM, which will then be analyzed as a solution to the problems and needs that have been defined above for the implementation of web-based CRM.

- Physical Design Phase

The purpose of this stage is to transform the business requirements statement into a design specification for the construction process. In other words, the design stage states how technology will be used in the new system.

- Construction and Testing Phase

The Construction phase is the stage of carrying out testing on individual system components and the system as a whole. After the construction is finished, the system testing is developed.

- Installation and Delivery Phase

In this phase, the system that has been built is operated and provide training to users on the use of systems that have been built.

\section{APPLICATION OF CRM}

In this study, the author uses the system development method, namely the Framework for the Application of System Techniques (FAST). FAST integrates all known popular approaches into a collection of agile methods or intelligent methods [9].

In the sales information system that will be developed, the concept of Operational CRM is applied that meet the following stages:

- Acquire

By applying the concept of web-based CRM will get new customers by promoting KFTD products through the website to convey what product information is available to facilitate customers in accessing the information needed with an attractive appearance.

\section{- Enhance}

One way to improve the relationship between KFTD and customers is by communicating with customers through the comments feature that can be used by customers when accessing a product page on the web. Besides, admin can give discounts on certain products. The discount is installed based on the provisions of the central KTFD.

- Retain

On the website that will be built, an online survey will also be provided to measure the level of customer satisfaction and loyalty. With the online survey and comment feature, it is expected that companies can find out the level of customer satisfaction and improve communication with customers so that companies can build business strategies to maintain relationships with customers.

\section{RESULTS AND DISCUSSION}

The result of this study is a website as a means of selling KFTD products based online. This sales information system has two users namely admin and customer.

\section{CONCLUSION}

By implementing a web-based Customer Relationship Management (CRM) at PT. Kimia Farma Trading and Distribution Palembang may help to improve relationships between customers and companies. Besides, with CRM the company can attract more customers, improve customer relationships, and maintain customer relationships better and improve company performance

\section{REFERENCES}

[1] Kadir, A., "Pengenalan Sistem Informasi". American Enterprise Institute for Public Policy Research 1-19. 2014.

[2] Westwood, John, "How to Write Marketing Plan". Jakarta: PT Elex Media Komputindo. 2006.

[3] Furqon, Ali, "Perancangan Aplikasi Sistem Informasi Penjualan Berbasis Microsoft Access 2007 pada Toko Syafa Collection". Laporan Akhir Politeknik Negeri Sriwijya. 2013.

[4] Buttle, "Customer Relationship Management Concept and Tools". Elsevier. 2007.

[5] Greenberg, Paul, "Customer Relationship Management at the Speed of Light". Berkeley: Mc-Graw Hill. 2002.

[6] Kalakota, R., \& Robinson, M, "E-Business 2.0

Roadmap for Success". Massachusetts: Addson Wesley Longman. 2001.

[7] Peranginangin, \& Kasiman, "Aplikasi WEB Dengan PHP dan MySQL". Yogyakarta: Andi. 2006.

[8] Whitten L, Jeffery, Bentley D, Lonnie, Dittman C, Kevin, "Metode Desain dan Analisis Sistem". Yogyakarta: ANDI. 2004. 